\title{
Vulnerability and virtue
}

Cite as: CMAJ 2021 August 16;193:E1257-8. doi: 10.1503/cmaj.210625

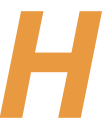

aving witnessed scenes of death innumerable times as a critical care physician, this is how I imagine my mother's death, thousands of miles away: her eyes are sunken and, in the heavy air, her breathing becomes slower and more erratic before it ceases permanently. Her pale, boney fingers lie motionless on the crisp white sheets. Her hands look cold and inanimate in their artificially natural pose. The air grows still and stiller, and in the emptiness of a sunless, soundless room, her body, once full of life, lies alone.

During the past year, we have all experienced and witnessed the separation of the sick and dying from their loved ones; we have all repeatedly donned protective gear to face an unnatural emptiness within rooms of suffering and death. Our garb cannot protect us from an overwhelming sense that we have collectively betrayed those who are suffering. Of course, these measures have been predicated on extraordinary challenges, but no amount of handwashing can absolve us of our shared accountability for the impact of the limited family presence on our patients, families and ourselves. Never again will we refer to families as "visitors." Without their presence, there is a heightening of grief and regret, a suspension of ritual; tension has usurped peace. ${ }^{1}$ In the absence of any prudent alternatives, how can we draw some good from this necessary evil?

He is young, looking around as his parents guide him down the hall. I sigh, relieved that he can finally visit, but sad that, after months in hospital, his sister's final hours have begun.

Children have thankfully escaped much of the morbidity and death of COVID-19, but they have been scathed by restrictions on family presence. Before COVID-19, our unit was abustle with the comings and goings of families bringing some measure of relief to a

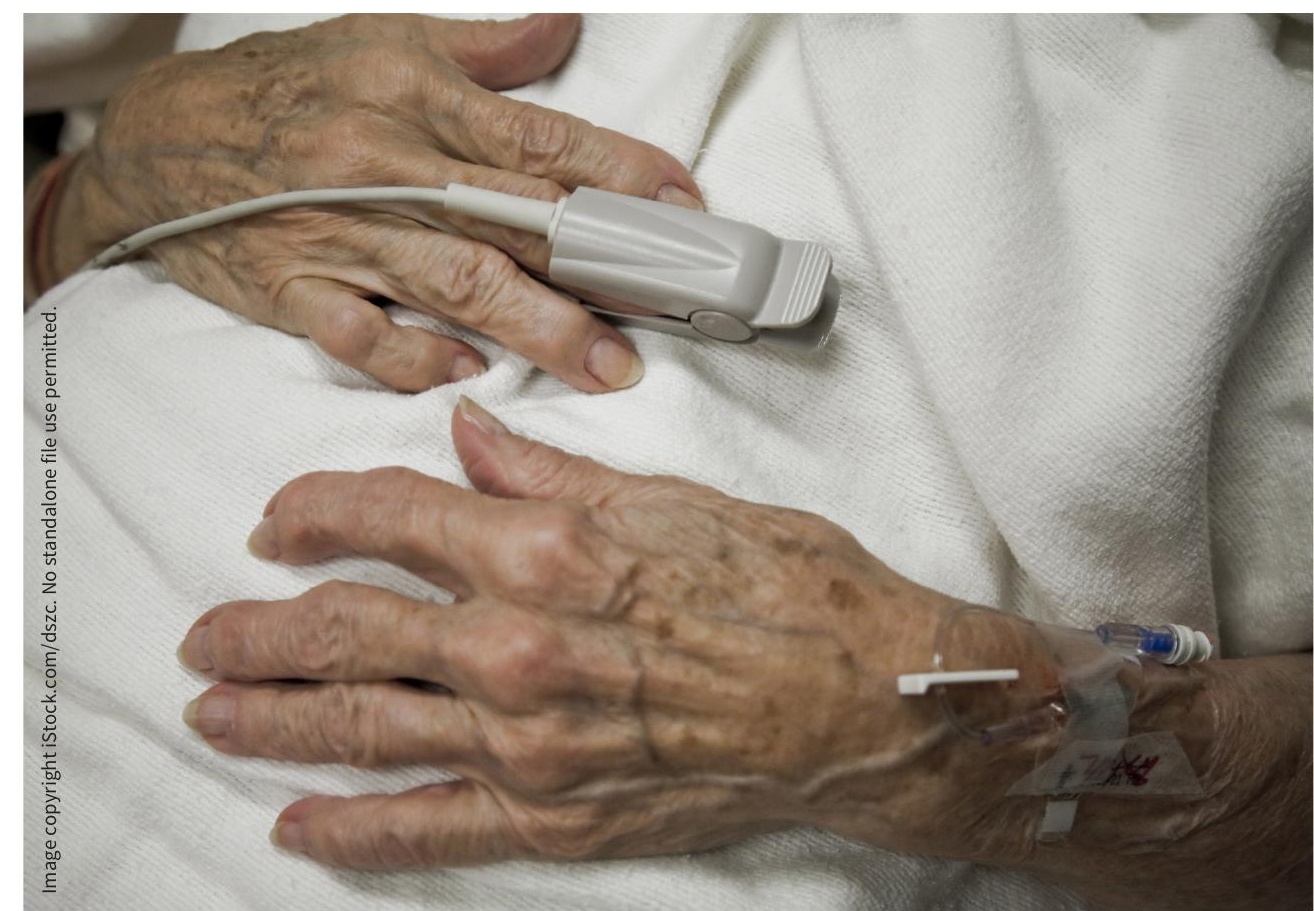

child who was recovering, or suffering, or dying. Our halls are now subdued with a preternatural somberness. We used to mutter among ourselves if a child's family was absent. Now, hidden behind a layer of necessary, but impersonal, protective equipment, burdened by our own pandemic experiences, we do our best to stand in for the family members who can't be there.

She is 10 years old, lying in bed, frightened by her diagnosis and by her isolation. Her family members are positive for SARSCoV-2 and cannot visit. Alone with her thoughts and fears, senses distorted from a host of medications and a foreign environment, she awakens and searches out my gaze. She claims my hand and I sit there as she drifts back to sleep.

The poet and civil rights activist, Maya Angelou, once wrote that "hands can touch with such a healing, irresistible tenderness." Love transcends physical distance, but physical touch still remains one of the strongest channels of human tenderness. Touch is a language unto itself, a potent gesture that establishes a human connection with caring and understanding, including between clinicians and patients. ${ }^{3}$ Today, our patients' journeys take place in the context of a highly contagious virus. We are at the bedside when family members are not. Despite our gowns, gloves and masks to protect us, touch has become foreign; we feel a new reluctance to reach out, physically, to each other or to a patient at their time of need.

Alone at her son's bedside, she is isolated from the rest of her family and friends. A language barrier adds to the distance between us. She seems anxious, but her son has been improving, and I smile behind my mask and visor and give a thumbs up. The next instant, her arms are wrapped around me with a sincere thankfulness and I freeze, appreciating this warm embrace, but almost recoiling from a human touch that has become so foreign. 
Before COVID-19, touch had already yielded its primacy to technology; bedside presence had become less pronounced and screens had become more visible than patients. ${ }^{4}$ We had built our own barriers to patient accompaniment long before we donned the accoutrements of this pandemic, and perhaps the latter have now unmasked a path to recalibrate what lies at the heart of our professional being.

During this crisis, we have learned much about ourselves, and about how to be present with our patients and families. We have learned that virtual care allows a real connection with others; surely it will outlast the current crisis in some form. ${ }^{5}$ We have learned how many challenges in communication are in our purview; the onus is on us to understand, navigate and advocate to overcome those barriers to access that are socially determined. And at the bedside, we have learned new sensitivities to silences, to wrinkled eyes, to tears slipping under masks, to body language and to words that command a fuller attention. When we cannot hug, and when our smile is mostly hidden behind a mask, then we doff any pretense and move beyond the face shields, the masks, the myriad new protocols and guidelines, to be fully present for the child and caregiver in front of us. This is the necessary accompaniment, the personalized medicine that precedes computer screens and genomic screens. ${ }^{6}$ Medicine's Science has grown tremendously over the past year - its Art cannot be left behind.

We started the pandemic poring over headlines about who is essential, and now we ponder what is essential in the lives we lead. Every time we don protective gear, we must also embrace a greater vulnerability, be more fully attuned to the child and family whose suffering and isolation demands that we open the heart of our professional being like never before.

\section{Catherine Proulx MD}

Department of Critical Care Medicine, Hospital for Sick Children, Toronto, Ont.

\section{Briseida Mema MD MHPE}

Department of Critical Care Medicine, Hospital for Sick Children and Department of Pediatrics, Faculty of Medicine, University of Toronto, Toronto, Ont.

\section{Andrew Helmers MD MHSc}

Department of Critical Care Medicine, Hospital for Sick Children; Department of Pediatrics, Faculty of Medicine, University of Toronto, Toronto, Ont.

\section{References}

1. Curley MAQ, Broden EG, Meyer EC. Alone, the hardest part. Intensive Care Med 2020;46: 1974-76.

2. Angelou M. A brave and startling truth. New York: Random House; 1995.

3. Horton R. Offline: touch - the first language. Lancet 2019;394:1310.

4. Zulman DM, Haverfield MC, Shaw JG, et al. Practices to foster physician presence and connection with patients in the clinical encounter. JAMA 2020;323:70-81.

5. Zulman DM, Verghese A. Virtual care, telemedicine visits, and real connection in the era of COVID-19: unforeseen opportunity in the face of adversity. JAMA 2021;325:437-8.

6. Hartzband P, Groopman J. Physician burnout, interrupted. N Engl J Med 2020;382:2485-7.

This article has been peer reviewed.

The brief vignettes herein represent true encounters.

Content licence: This is an Open Access article distributed in accordance with the terms of the Creative Commons Attribution (CC BY-NC-ND 4.0) licence, which permits use, distribution and reproduction in any medium, provided that the original publication is properly cited, the use is noncommercial (i.e., research or educational use), and no modifications or adaptations are made. See: https://creativecommons. org/licenses/by-nc-nd/4.0/ 